\title{
Emotionella positioneringar i elevers berättelser om ämnet modersmål
}

\author{
Birgitta Ljung Egeland
}

Institutionen för språk, litteratur och interkultur, Karlstads universitet

\begin{abstract}
Syftet med artikeln är att generera kunskap om modersmålselevers erfarenheter om skolämnet modersmål genom att studera elevers emotionella positioneringar i berättande och berättelser om sina relationer till språk. Utgångspunkt tas i livsberättelseintervjuer genomförda vid tre tillfällen med två grundskoleelever med migrationsbakgrund, som bor och går i skolan på två mindre orter i Sverige. Intervjuerna gjordes inom ramen för ett avhandlingsprojekt som handlade om elevers berättelser om migration och tillhörighet. I artikeln fokuseras både vad och hur de berättar om sina erfarenheter av språk och ämnet modersmål i skolan och hur erfarenheterna ges mening $\mathrm{i}$ berättandet. Teoretisk utgångspunkt tas $\mathrm{i}$ synen på berättelser som socialt situerade handlingar och identitetsframträdanden samt i begreppet investering, för att förstå engagemang i språkinlärning. Genom narrativ positioneringsanalys görs analysen i flera nivåer och särskilt fokus läggs på de emotioner som framträder genom de positioneringar eleverna gör på olika språkliga nivåer och med hjälp av olika resurser. I berättelserna framträder glädje och stolthet, men också mer ambivalenta känslor kopplade till modersmålet och modersmålsämnet. Eleverna beskriver hur modersmålsundervisning i skolan är viktig och betyder mycket på olika sätt och framstår som en språkligt och kulturellt identitetsstärkande praktik.
\end{abstract}

\section{INLEDNING}

Syftet med den här artikeln är att generera kunskap om modersmålselevers erfarenheter om skolämnet modersmål genom att studera elevers emotionella positioneringar i berättande och berättelser om sina relationer till språk. Det 
gör jag genom att ta utgångspunkt $i$ två elevers, Jamils och Yasmines, berättelser och beskriva hur en narrativ positioneringsanalys (Bamberg, 1997; 2004) med fokus på emotioner kan ge sådan kunskap. Min ingång är att just narrativ forskning gör det möjligt att sätta elever i centrum, som sociala aktörer och experter på sina egna liv (Ansell, 2005; Brady \& Graham, 2019; Garvis m.fl., 2015). Det innebär att elever positioneras med agens att vilja förstå, delta $i$ och förändra världen. I den här studien är det yngre elever som intervjuas och målet med att be eleverna berätta är att ge utrymme för komplexitet och motsägelser. Fortfarande intervjuas oftare lärare eller andra vuxna om undervisning med yngre elever, men beskrivningar av elevers liv i och utanför skolan som är skapade av lärare eller föräldrar är av naturliga skäl ofta tunnare, har oftare fokus på brister och kan dölja olika former av maktrelationer (Morgan, 2004). Teoretiskt utgår artikeln från synen på berättelser som socialt situerade handlingar och identitetsframträdanden. Det gör att det får betydelse hur och varför något berättas och vilka funktioner berättandet och berättelsen fyller i ett specifikt sammanhang (De Fina \& Georgakopoulou, 2012; Mishler, 1999). En ytterligare utgångspunkt $i$ artikeln är att tankar och emotioner är sammanflätade fenomen, som kan ta sig uttryck i just berättelser. Emotioner ses därför här ha narrativ kvalitet. När känslor beskrivs sätts de ofta in i en narrativ struktur, $i$ en situation där något händer som ger upphov till känslan och där känslan får en funktion. I den forskning som exempelvis intresserat sig för olika erfarenheter av migration ses emotioner ofta som en konstituerande del av migrationsprocesser (Skrbiš, 2008). Bland andra Ahmed (2004) argumenterar för att emotioner är något som spelar en avgörande roll för hur individer och kollektiv rör sig i riktning mot eller ifrån varandra.

Materialet som ligger till grund för artikeln är således livsberättelseintervjuer genomförda med elever med migrationsbakgrund, som bor och går i skolan på två mindre orter i Sverige. Intervjuerna gjordes inom ramen för ett avhandlingsprojekt som fokuserade på elevers berättelser om migration och tillhörighet (Ljung Egeland, 2015). I den här artikeln presenterar jag med hjälp av två av elevernas berättelser hur man genom narrativ positioneringsanalys (Bamberg, 1997, 2004) och med fokus på emotioner kan visa hur eleverna genom att berätta om modersmålsundervisningen, både explicit och implicit, också säger något om sig själva i relation till andra och om modersmålsämnets betydelse i och för skolan. Modersmålsämnet diskuteras och ifrågasätts mer än andra ämnen i skolan och nyligen publicerades en utredning gjord på uppdrag av regeringen utifrån behovet av åtgärder när det gäller undervisningen $\mathrm{i}$ modersmål $\mathrm{i}$ grundskolan och motsvarande skolformer (SOU 2019:18).

Modersmålsundervisning ska erbjudas elever som har en vårdnadshavare med ett annat modersmål än svenska om språket är elevens dagliga umgängesspråk i hemmet och eleven har grundläggande kunskaper i språket. Skolans skyldighet att anordna modersmålsundervisning villkoras ofta av antal elever 
och att lämplig lärare finns. Modersmål har inte som andra ämnen någon minsta garanterad undervisningstid och ofta anordnas undervisningen utanför ordinarie skoltid. Ämnet är frivilligt och frågan om tillgången är också avhängig skollednings, vårdnadshavares och elevers syn på ämnets betydelse. Viktiga frågor som diskuteras både i och utanför skolans värld handlar om vilka vinster undervisningen har för eleverna, som bättre svenska, högre studieresultat, kulturell stolthet och möjligheten att kommunicera med den egna etniska gruppen. I ovan nämnda utredning (SOU 2019:18) påpekas intressant nog att högre studieresultat inte framstår som vårdnadshavarnas främsta anledning till att välja modersmålsundervisning för sina barn.

Om och hur modersmålsämnet kan vara betydelsefullt på olika sätt för olika elever skriver Straszer och Wedin i introduktionskapitlet till antologin Modersmål, minoriteter och mångfald (2020). Det handlar om modersmålet som resurs för individens språk- och identitetsutveckling, men också som kunskapsresurs för både individen och samhället. De lyfter de sociala värdena för eleven dels genom större möjligheter till aktivt deltagande i modersmålets språkgemenskaper, dels genom att modersmålsläraren kan vara en viktig länk mellan hem och skola (se också Duek, 2017; Ljung Egeland, 2018; Sharif, 2016; Straszer \& Wedin, 2018; Vuorenpää \& Zetterholm, 2020). Elevers perspektiv på skolans undervisning ger viktig kunskap, vilket gäller även yngre elever. Reath Warren (2020) ger just en presentation av forskning som rör modersmålsundervisning i Sverige utifrån ett elevperspektiv. Hon presenterar också sin egen studie där fokusgruppsdiskussioner gjorts med grundskoleelever på ett innovativt sätt med hjälp av frågekort. I sin diskussion lyfter Reath Warren en monoglossisk norm som präglar skolan och därmed också modersmålsämnet, exempelvis genom att användning av andra språk som resurs $i$ undervisningen inte uppmuntras eller genom att eleverna får välja endast ett modersmål att studera även om de har flera umgängesspråk $i$ hemmet. I den studie varifrån materialet till den här artikeln är hämtat, är perspektivet elevernas och samtliga har ett eller flera andra språk än svenska som levande språk hemma och deltog då studien inleddes i modersmålsundervisning (Ljung Egeland, 2015).

\section{TEORETISKA UTGÅNGSPUNKTER}

Narrativ metod har beskrivits som "the study of stories" (Polkinghorne, 2007, s. 471) och är en betydande ansats inom många forskningsfält, bland annat det utbildningsvetenskapliga (Clandinin, Pushor och Orr, 2007). I berättande och berättelser sammanflätas personliga erfarenheter, sociala förhållanden, historiska omständigheter, kulturella referensramar samt uppfattningar och kan därför säga något viktigt också om samhället och de diskussioner som är närvarande i skolan och som på olika sätt villkorar verksamheten (Pérez Prieto, 2006). Berättande sker således inte i ett vakuum, utan dominerande diskurser, 
om exempelvis flerspråkighet och modersmålsundervisning, formar också det som berättas.

\section{Berättelser som sociala handlingar}

Genom berättande kan den som berättar placera sig själv och andra i världen och genom berättelser kan erfarenheter bli mer begripliga genom att de tolkas och omtolkas och en berättelse får olika innebörd beroende på i vilket sammanhang den berättas, för vem och i vilket syfte (se exempelvis Burr, 2003; Karlsson, 2006; Mishler 1999; Pérez Prieto, 2006). Berättelser är i ett sådant konstruktionistiskt perspektiv något som skapas i samspel. Det som sker när någon berättar om sitt liv är en kreativ, meningsskapande process och genom den utforskas och förklaras världen. Hur man förstår sig själv påverkar också hur man kan uttala sig om världen utanför (Freeman, 2010). En annan viktig dimension är att mycket av det man minns är sådant som man har upplevt tillsammans med andra och man får också under hela uppväxten hjälp av familj och vänner i att sortera i minnen och hur sådant som hänt ska minnas (Randall, 2010). Man har således många medberättare eller medkonstruktörer i sina berättelser (Ochs \& Capps, 2001) och i ett intervjusamtal blir också jag som forskare medkonstruktör.

I ett intervjusamtal kan man också positionera sig på olika sätt i relation till den som lyssnar beroende på sammanhanget och för att exempelvis visa antingen distansering från eller solidaritet med andra. Berättelser och positionering hör på så sätt samman om man utgår ifrån att människor ständigt positionerar sig själva och andra i berättelser och positioneringen hänger då ihop med det som händer i berättelsen (Harré m.fl., 2009; van Langenhove \& Harré, 1999). En och samma elev kan positionera sig som exempelvis dotter $i$ ett sammanhang, men som elev i ett annat eller som svensk respektive kurd (Brinkmann, 2008; 2010). En position är något som hela tiden förhandlas i socialt liv och kan vara mer eller mindre självvalda eller påtvingade. De positioneringar eleverna gör i intervjusamtalen blir då avhängiga av exempelvis vem som frågar, hur den som frågar och den som svarar är positionerade i förhållande till varandra och var frågan ställs. I den här studien beskriver jag vad man kan kalla självpositioneringar hos eleverna. Positionering som analytiskt begrepp är i sig öppet och innehållslöst och närmast synonymt med kommunicering (Ongstad, 1999). Det måste alltså kombineras med något man vill fokusera på. Jag har därför ett analytiskt fokus på det jag kallar för emotionella positioneringar i elevernas berättelser, vilka hjülper mig att förstå elever med migrationsbakgrund och deras erfarenheter av språk och ämnet modersmål.

Positioneringar handlar således om förhandling och det gäller också emotioner. Elevernas berättade erfarenheter av modersmål öppnar för ett analytiskt fokus på just berättelser och emotioner. Deras erfarenheter skapar känslor och utifrån syftet med den här artikeln blir det både relevant och 
värdefullt att studera hur emotioner relaterar till berättelser om att vara flerspråkig och delta i modersmålsundervisning. Emotioner bär på specifik kunskap, motiverar till handling i olika riktningar och ger livet mening och innehåll (Madrid m.fl., 2013). Emotioner är en viktig del av den sociala interaktionen och enligt Scheff och Starrin (2002) antas emotioner vara biologiskt förankrade samtidigt som sociala omständigheter utgör en del av den emotionella erfarenheten. De menar att skam och stolthet är exempel på emotioner som påverkas av den sociala interaktionen och individens självkänsla och är avhängigt både den egna och andras förståelse av mer eller mindre explicita föreställningar om vad det innebär att känna rätt känsla av rätt anledning vid rätt tidpunkt och i lagom mängd. Att känna exempelvis skam hänger då ihop med en förståelse för att det man har gjort ses som skamfullt av en annan människa. Emotioner är relaterade till hur man ser på sig själv i relation till andra och därmed får också kulturella föreställningar betydelse för vad som ses som fel och orättvist och på så vis är emotioner och tankar sammanvävda (Scheff \& Starrin, 2002).

\section{Investering}

Norton Peirce (1995) och senare Darvin och Norton (2015) använder begreppet investering (investment) för att förklara och ge djupare förståelse för engagemang i språkinlärning. Det är ett begrepp som är användbart här för att diskutera hur eleverna positionerar sig i sina berättelser om språk och ämnet modersmål. Istället för motivation använder Darvin och Norton (2015) investering om individers upplevelser av engagemang $i$ att lära sig ett språk. Engagemanget ska förstås i ljuset av de tre begreppen identitet, kapital och ideologi. Darvin och Norton (2015) vill med sin investeringsmodell (model of investment) visa hur man investerar i språkinlärning, eftersom man därigenom kan tillägna sig en rad symboliska och materiella resurser utan att ge avkall på sin identitet. Denna investering sker i skärningsfältet identitet, kapital (ekonomiskt, socialt, kulturellt, symboliskt) och ideologi. Ideologier styr vad som kan betraktas som norm i samhället och skapar strukturer som är både inkluderande och exkluderande. Språkinlärares investering $\mathrm{i}$ att tillägna sig nya språkkunskaper är också knutet till en föreställd identitet (imagined identities), det vill säga vilken framtid man ser framför sig och hur man ser på sig själv utifrån tidigare erfarenheter. Att investera $i$ att lära sig ett språk är därmed ett samspel mellan de egna tankarna och önskningarna om framtiden och samhällets diskurser om språk och migration.

\section{METOD OCH MATERIAL}

Artikeln tar utgångspunkt $\mathrm{i}$ intervjumaterial från min avhandlingsstudie Berättelser om tillhörighet: om barn med migrationsbakgrund på en mindre ort (Ljung 
Egeland, 2015). Syftet med den studien var att genom livsberättelseintervjuer få fördjupad kunskap om barns berättade erfarenheter av migration och tillhörighet, för att samtidigt få kunskap om skolan och barns uppväxtvillkor. I den här artikeln fokuserar jag på barnens erfarenheter som modersmålselever och det är deras erfarenheter av ämnet modersmål som specifikt står i fokus. Intervjumaterialet har med utgångspunkt $i$ en narrativ ansats analyserats som berättelser. I avsnittet nedan beskrivs hur konstruktionen och bearbetningen av forskningsmaterialet har gått till. Urval och deltagare redovisas och jag uppmärksammar den hänsyn jag har tagit till att deltagarna är barn och att de har ett annat modersmål än svenska, vilket också inkluderar forskningsetiska vägval. Avslutningsvis ges en beskrivning av analysprocessen.

\section{Deltagare}

Deltagarna i studien är elever mellan nio och tretton år gamla och de går på två skolor i två olika mindre kommuner och har olika språklig bakgrund. Skolorna valdes utifrån att de är belägna på två mindre orter. De två elevernas berättelser som presenteras $i$ artikeln är de enda $i$ sin klass med utländsk bakgrund och de enda med sin specifika språkbakgrund. Den icke-urbana kontexten är viktig såtillvida att andra språk än svenska inte hörs dagligen varken i skolan eller i samhället. Elevernas vårdnadshavare samtyckte först efter att ha fått studien presenterad för sig på sitt modersmål av modersmålslärarna och vid första intervjutillfället gavs särskild information till eleverna.

I den här artikeln tas utgångspunkt $i$ två av elevernas berättelser om modersmål, nämligen Jamils och Yasmines, eftersom de båda berättade mycket och innehållsrikt om språk och tillhörighet $\mathrm{i}$ och utanför skolan. Det är eleverna själva som har berättat om sin migrationshistoria, sin familj, skolan, kamrater och var de bor. Jag har inte haft tillgång till någon annan information om dem än det de har berättat vid intervjuerna. Namnen är pseudonymiserade. Båda eleverna är födda i Sverige och Jamil har sin bakgrund i Syrien och Turkiet och Yasmine i Irak. De har ett eller flera andra språk än svenska som levande språk hemma. Också namnen på skolorna är pseudonymiserade, Jamil går i årskurs 5 på Åbyskolan och Yasmine i årskurs 4 på Vikenskolan.

\section{Att intervjua eleverna}

Individuella intervjuer genomfördes i skolan och varje intervju varade i ungefär en timme. Eleverna intervjuades vid tre tillfällen och utan tolk. De är båda födda i Sverige och talar svenska obehindrat. Intervjuerna resulterade i ett material som sammantaget består av cirka 6 timmar digitalt inspelade samtal motsvarande drygt 100 sidor i intervjuutskrifter.

Intervjuerna var samtalsliknande med utgångspunkt i frågeområden snarare än färdigformulerade frågor och de frågor jag ställde utgick ifrån det eleverna berättade. Därigenom formades intervjun utifrån elevernas svar. Jag ser intervjuerna som fokala livsberättelseintervjuer och har använt olika vägar 
för att stödja eleverna i deras berättande och de berättade med hjälp av i huvudsak livslinjer och sociala nätverkskartor (för beskrivning se Ljung Egeland, 2015). Livslinjen används ofta i samband med livsberättelseintervjuer och omfattar händelser som kan betraktas som skelettet i en livshistoria (Bjerén \& Elgqvist-Saltzman, 1994). Kartor över orten och skolområdet samt världskartan användes vid samtliga intervjuer.

Förhoppningen har varit att intervjun ska upplevas som ett samtal snarare än ett förhör samt att eleverna skulle ges möjlighet att berätta det de tycker är viktigt och vill berätta om. I materialet finns många fylliga berättelser om familj, kompisar, släkt och resor till ursprungslandet. Dock var elevernas svar ibland korta och fragmentariska, särskilt vid första intervjun, men också beroende på personlighet och om vi talade om något som de var mer eller mindre intresserade av. Vid intervjuerna har jag därför frågat efter konkreta händelser och följt upp deras spontana berättelser. Jag har ofta deltagit i att utveckla innehållet och strukturen $\mathrm{i}$ dem genom att exempelvis försöka sammanfatta, försöka hitta ord, fylla i ord, stämma av, fråga om jag har uppfattat rätt och försöka fånga upp något i samtalet som vi har kunnat lyfta ut och uppmärksamma tillsammans; det man kan kalla för delad uppmärksamhet i samtal (Morgan, 2004).

Jag hade kunnat intervjua eleverna på deras modersmål med hjälp av tolk, vilket jag valde att inte göra. Jag har arbetat med tolk tidigare och vet att tolkens skicklighet kan variera och att de ibland omformulerar det som sägs (Fontes, 2008; Keselman, 2009). Jag vet också att närvaron av en tolk, som eleven kanske känner till eller rent av känner, kan ha stor betydelse för vad som sägs i samtalet. Vid intervjuerna har heller inte betoningen legat på att kunna uttrycka sig precist eller exakt. Eleverna är vana att hitta strategier för att uttrycka sig på svenska och de situationer i samtalet där vi har frågat oss vad den andre egentligen menar har mestadels varit då de har berättat om sådant som har med ursprungslandets domän att göra.

Genom att vara en aktiv samtalspartner har jag också varit en deltagare i samtalet och på så sätt medskapare till det som sägs under intervjun. Eilard (2009) lyfter fram att den stora skillnaden mellan att intervjua barn respektive vuxna är den asymmetriska maktrelationen. Särskilt när det gäller skolelever är det viktigt att vara uppmärksam på det som i skolbaserad forskning talas om som så kallat inlärt samtycke snarare än informerat samtycke (David m.fl., 2001; Löfdahl, 2012). Intervjuer som genomförs i skolan kan lättare förknippas med en undervisningssituation där den vuxne är den auktoritetsperson som har rätt att ställa frågor och barnet har skyldighet att svara. Av bland annat etiska skäl måste barns integritet respekteras. Ibland vill de inte svara, ibland kan de inte och ibland förstår de helt enkelt inte och det är viktigt att varken över- eller underskatta barns förmåga och att ha fokus på att lyssna noga. När jag har uppfattat att samtalet hamnat på sidospår, har jag sett det som viktigt att inte alltid försöka styra samtalet. Det finns mycket av värde $i$ 
elevernas berättande som inte alltid framgår direkt, men som visar sig vid analyserna.

I direkt anslutning till varje intervju gjorde jag en kort sammanfattning av mina huvudintryck från samtalet, så kallade memosanteckningar som inledning till en första analys, inspirerad av analysförfarande ofta använt i exempelvis Grounded Theory (Montgomery \& Bailey, 2007; Bryman, 2011). Anteckningarna gjordes i syfte att försöka beskriva i ord det jag hade observerat under intervjuerna och som inte fångades upp i ljudinspelningarna. Exempelvis känslor, tonfall, kroppsspråk, ansiktsuttryck, minspel, rörelse i rummet och engagemang i samtalet beskrevs så som jag uppfattade det. Jag antecknade även andra tankar om vad jag undrade mer över och själv gärna ville fråga mer om eller vad som hade verkat viktigt för eleverna i samtalet.

Det är viktigt att tolka elevernas berättade erfarenheter med försiktighet. Vuxnas förförståelse har benämnts adultism i analogi med begrepp som egocentrism och etnocentrism (Alanen, 2001), som ett sätt att beskriva hur barns perspektiv ändå tolkas utifrån ett vuxenperspektiv. Ett annat sådant begrepp är chronocentrism (Dencik, 1995; 1999), vilket handlar om samtidsblindhet och att det alltid finns en diskrepans mellan det vuxna tror sig veta om barns villkor och hur de upplevs av barnen själva. Vid analyserna av elevernas berättelser har det blivit tydligt att intervjusamtalen har möjliggjort olika sätt att svara och berätta och att eleverna har många olika ingångar. Med utgångspunkt i ett narrativt perspektiv har jag försökt ge dem möjlighet att berätta om det som verkligen betyder något för dem i deras vardag. Mina frågor under intervjusamtalen tog utgångspunkt i det de berättade och jag försökte på olika sätt bidra till att intervjusamtalen undersökte hur eleverna skapade mening $i$ sina liv genom att de berättade om sina erfarenheter i både nutid, dåtid och framtid.

\section{Narrativ analys}

Det material jag haft som grund för mina analyser är dels de transkriberade intervjuerna, dels de memosanteckningar jag har gjort efter varje intervju och som har särskilt fokus hur eleverna har berättat och på sådant som har med min upplevelse av stämningen i samtalen att göra. Jag har valt att inledningsvis göra en narrativ analys av materialet. Utgångspunkten för analysen är Polkinghornes (1995) uppdelning av den narrativa forskningsprocessen i två olika metoder: narrative analysis och analysis of narratives. Jag har använt dessa två metoder i två steg $\mathrm{i}$ min analys, för att det ger möjlighet att både konstruera berättelser utifrån materialet och analysera dessa konstruerade berättelser med hjälp av positioneringsanalys. I narrativ analys för forskaren samman fragmenterad data och (re)konstruerar till en koherent berättelse snarare än delar upp i olika kategorier. Clandinin m.fl. (2006) kallar narrativ analys fictionalization, det vill säga att skapa narrativa konstruktioner bland annat i syfte att 
skydda deltagarnas identiteter och att fånga läsarens fantasi för att förstå mer och på ett fördjupat sätt.

I den andra av Polkinghornes (1995) beskrivning av metoder, analys av narrativ, söker forskaren kategorier och teman i befintliga berättelser på liknande sätt som i annan kvalitativ analys. Jag har således använt båda metoderna $i$ två steg och det första steget kan beskrivas som konstruktion av sammanhängande berättelser i jag-form. Ibland handlar det om att föra samman delar av det som har berättats under samtliga tre intervjuer. Huvudinnebörden i det som sägs formuleras om i färre ord, dock hela tiden med elevernas egna ord som utgångspunkt (för en utförlig beskrivning av hur konstruktionen av berättelser har gått till, se Ljung Egeland, 2015). Till den här artikeln konstruerades i detta steg två stycken berättelser utifrån intervjumaterialet. Genom att konstruera berättelser har jag velat kontextualisera händelserna och på så sätt visa komplexiteten i elevernas positioneringar som rör språk och modersmål och hur de förankras i tid och rum. Analysens nästa steg innebär en analys av dessa berättelser med fokus på de emotionella positioneringar kopplade till språk och ämnet modersmål som framträder.

Det första steget $i$ analysen innebär således att konstruera berättelser utifrån datamaterialet. Det andra steget $i$ analysen innebär det som med Polkinghornes terminologi kan sägas vara analys av narrativ, det vill säga att analysera de konstruerade berättelserna. I det här steget har jag inspirerats av Bambergs narrativa positioneringsanalys (1997; 2004). Bambergs utgångspunkt är intresset för identitetsskapande och han lyfter fram hur positionering i berättande sker i flera nivåer. Bambergs modell utgörs därför av flera analytiska nivåer, vilket innebär att i en första nivå vara intresserad av vilka karaktärer som finns med i berättelsen och hur de positioneras i förhållande till varandra i berättelsen. Intresset riktas också mot hur eleverna positionerar sig som någon som har eller inte har handlingsmöjligheter och hur det kan växla. Det är de karaktärer som eleverna lyfter fram som betydelsefulla i relation till språk och ämnet modersmål som lyfts fram här. På nästa nivå riktas intresset mot hur eleverna positionerar sig i relation till mig som intervjuar i samtalet och ibland också till en mer eller mindre närvarande större publik. Här riktas fokus mot några av de narrativa resurser eleverna använder för att positionera sig, exempelvis ansiktsaktivitet, bildspråk och retoriska frågor där jag lutar mig mot de memosanteckningar jag gjort efter intervjuernas slut. Dessa två nivåer är i fokus i artikelns resultatdel. På en tredje nivå riktas intresset mot hur språket används för att positionera sig $\mathrm{i}$ förhållande till sig själv i en större kontext utanför själva berättelsesituationen, som dominanta berättelser (master narratives), och denna nivå kommenteras $\mathrm{i}$ diskussionsdelen. Bamberg (1997) menar att i berättande framträder en tillfällig version av den man är, hur man vill bli uppfattad av den eller dem som lyssnar och hur man vill att de andra karaktärerna i berättelsen ska uppfattas. 


\section{Analys med fokus på emotionella positioneringar}

Emotionell positionering definierar jag som de emotionella handlingar eller yttranden som framträder implicit eller explicit i berättelsen och som bidrar till någon form av sociala ställningstaganden och till att eleverna förhandlar och skapar olika bilder av sig själva och andra, exempelvis genom att beskriva ambivalenta känslor kopplade till resor till ursprungslandet som både "läskigt och kul" eller "fattigt, men skönt". Med fokus på emotioner inkluderar jag både de lingvistiska och icke-lingvistiska resurser eleverna använder under intervjusamtalen för att positionera sig (Bucholtz, 2009; Eckert, 2008; Ochs, 1993). Indikatorer på positioneringar i berättelsen kan vara hur de refererar till sig själv och andra i berättelsen (exempelvis genom personliga pronomen), hur de refererar till värderingar om vad som är rätt och fel eller modaliteten hos det de säger (exempelvis grad av osäkerhet). Indikationer på emotionella positioneringar kan i sin tur vara explicita verbala uttryck som "Jag känner...", bildspråk, emfas på ord, intonation eller repetition, men också annat som indikerar starka känslor, som gester, kroppsspråk, ansiktsuttryck, eller fysiska indikatorer, som att man rodnar. I mina memosanteckningar har jag i direkt anslutning till intervjun skrivit ned hur jag har uppfattat att eleverna har uttryckt emotioner utifrån hur jag har tolkat samtalen.

\section{RESULTAT}

Nedan presenteras utdrag ur Jamils och Yasmines berättelser utifrån syftet att generera kunskap om modersmålselevers erfarenheter om skolämnet modersmål genom att studera deras emotionella positioneringar i berättande och berättelser om sina relationer till språk. Dessa erfarenheter förankras i tid och rum genom att de presenteras som berättelser i jag-form och sätts i ett sammanhang.

\section{Jamils berättelse}

Jamil går i årskurs fem på Åbyskolan. Hans mamma är från Syrien och hans pappa från Turkiet. Han är själv född i Sverige och har bott i Åbyn hela sitt liv. Jamils mamma arbetar som modersmålslärare $i$ arabiska. Han har modersmålsundervisning $\mathrm{i}$ arabiska med en annan lärare, men ingen undervisning $\mathrm{i}$ turkiska. Så här berättar Jamil om sin familj och sina språk:

Jag känner mig udda här i Åbyn, som en annan slags svensk. Mina föräldrar pekar på ena armen och säger, Turkiet. Och så i hjärtat, Sverige och den här andra armen, Syrien. Jag har olika delar i mig. Båda mina brorsor de är födda i Turkiet och jag är född här i Sverige. Fast det känns inte så. Alltså min mamma är från Syrien och min pappa är från Turkiet, då känns det fortfarande inte som 
att jag är från Sverige. Jag försöker lära mig turkiska och så försöker jag lära mig syriansk arabiska. Pappa pratar inte turkiska med mig, inte med mig, han pratar svenska med mig. De har bestämt att han pratar svenska med mig. Min mamma pratar arabiska med mig. Jag har modersmål i arabiska, men inte i turkiska. Jag borde lära mig turkiska.

Varje sommar åker vi till Turkiet. Och bor hos farmor. Vi försöker bygga ett hus där. Mest är vi där, för det är släkt där. Och så, min farmor, hon är värsta såhär...hon är gammal, så är hon verkligen jättesträng fortfarande. Fast hon kan vara snäll ibland. Det...lite svårt att förklara...lite såhär, om man gör fel så blir hon jättesur. Jag har hälsat på i en skola i Turkiet. Det var med min kusin. Deras skola är typ 1905 eller någonting. Det är typ såhär ganska gammalt och slitet. Har du sett såhär på TV de här reklamerna med Unicef "Alla barn ska få skola" och allting... De hade typ såna bänkar som där och allting. Och när en ny kommer så måste de samlas runt och fråga dig "Vad heter du?" tusen gånger. De bara kom fram såhär. De pratar också arabiska, där jag var. Det kunde nästan alla där. De jag träffade. Men, det finns ju ställen där de inte kan arabiska. Vi har ett hus $\mathrm{i}$ en annan del av Turkiet, fast där kan ingen arabiska, som jag vet. Men jag pratar mest arabiska, där i Turkiet. Min mamma, hon lär mig ju. Men när hon pratar så vill hon mest att jag ska prata arabiska. När jag inte kan så frågar jag henne, såhär.

Jag har en annan som lärare i modersmål i skolan. Men det känns som att jag har dålig undervisning och inte får den här hjälpen jag vill ha. Min mamma säger "försök" och då tänker jag - ja det kanske funkar då. Ibland känns det som att jag borde gå i en arabisk skola. När jag brukar öppna till exempel matteboken, det känns som att när det står såhär svenska och allting, då känns det som att det ska stå turkiska eller arabiska. Att det känns som att det hade varit lättare för mig. Alltså, ibland vill jag lära mig om sånt som handlar om Turkiet eller som handlar om Syrien, eller så. 
Som där i Turkiet, där har vi typ inga skogar eller någonting, de har ju bara träd som typ fruktträd. I Turkiet, där brukar jag, när min pappa ska typ hämta frukt eller något, då vill jag följa med för att se hur han plockar frukt. Han brukar kasta sten på frukten så den ramlar eller något. Och så får man skjuta på fåglar med slangbella. Alltså, när vi åkte till Turkiet när jag gick i trean, alltså Turkiet är ett land som ser fattigt ut, fast det är mycket skönare. Då frågade jag pappa såhär "Hur var det när du var liten?” Då började han berätta en massa berättelser. Och min pappa brukar kalla mig kompis då, efter en berättelse kallar han mig kompis. Jag gillar hans berättelser.

Släkten, vi har inte så mycket släkt nära oss och så, men pappa, han är ju mest och jobbar. Och mamma, hon är hemma och har ont i nacken, tror jag. Hon gör inte så mycket. Jag har min morbror och moster och kusiner i Skåne. Två tjejkusiner. En som pussar mig och en som sminkar sig. Fast de har typ världens svåraste namn. Jag kan inte såhär syriska och turkiska namn. Min mamma blir lite förvånad över det fast hon vet, fast hon fattar ju ändå. Hon vet att jag är svensk och inte kan sådär mycket om arabiska. Så jag kan nästan inga såna namn. Vi träffas inte så ofta.

Den första nivån i analysen handlar om vilka karaktärer som finns med i berättelsen och hur de positioneras i förhållande till varandra (Bamberg, 1997; 2004). Det är de karaktärer som Jamil explicit eller implicit lyfter fram som betydelsefulla för hans relationer till språk som blir viktiga. På den här nivån riktas också intresset mot hur Jamil positionerar sig som någon som på olika sätt har eller inte har handlingsmöjligheter. Det finns flera karaktärer som framträder som viktiga i den här delen av Jamils berättelse. Hans familj med mamma, pappa och två äldre bröder som bor i Åbyn, farmor och andra barn i Turkiet och släkten i södra Sverige samt modersmålsläraren i arabiska.

En annan slags svensk - Jamil positionerar sig själv och karaktärerna i berättelsen Jamil positionerar sig explicit i det att han säger "en annan slags svensk". Redan från början i intervjun diskuterar han med sig själv fram och tillbaka om det är så att han är svensk eller inte och om han känner sig svensk eller inte. Det gör han trots att jag inte alls frågar om det. Det är ibland svårt för mig att veta om det är något han själv funderar mycket på eller om det är 
något han förutsätter att jag vill att han ska resonera om. Jamil är den elev i studien som har gjort flest resor till ursprungslandet, det vill säga i det här fallet till pappas ursprungsland. Han har dock aldrig varit i mammas ursprungsland Syrien och berättar inte något om sina tankar om att resa dit. Jamil positionerar sin mamma som den som lägger ner arbete för att han ska utveckla sin arabiska. Modersmålsläraren, eller snarare undervisningen, positioneras genom det Jamil säger som någon som inte kan fånga upp det Jamil själv känner att han vill få ut av modersmålsundervisningen. Mamma och pappa bestämde att de inte ska prata turkiska hemma. Sammantaget positionerar sig Jamil som någon som inte ges så stora handlingsmöjligheter att agera och forma sina relationer till språk så som han skulle vilja. Detta framgår också i andra delar av Jamils berättelse där han beskriver en känsla av utanförskap på den mindre orten när det gäller bland annat kompisar och socialt nätverk för familjen (se Ljung Egeland, 2015).

Jamil åker till Turkiet i stort sett varje sommar och ibland till en del där han kan kommunicera på arabiska och ibland till en del av Turkiet där det inte är möjligt. Det är mot den bakgrunden Jamil berättar om sin flerspråkighet och vad modersmålsundervisning betyder och skulle kunna betyda. Vid besöket $i$ skolan i Turkiet vill alla barnen komma fram och hälsa på honom och han känner sig olik dem och det är svårt att prata. Samtidigt som han med svenska ögon berättar om den gamla och slitna skolan och beskriver Turkiet som fattigt finns också känslan av att Turkiet är mycket "skönare". Jamil positionerar Turkiet som en viktig del av hans identitet, både explicit när han beskriver hur Turkiet representerar en del av hans kropp och mer indirekt $i$ det han bland annat berättar om att han borde lära sig turkiska. Han upplever att han inte har tillgång till språket och det blir tydligt hur modersmålsundervisning i fler språk skulle kunna stärka Jamils identitetsutveckling och ge möjlighet till egna val (se Cummins, 2017; Straszer \& Wedin, 2020). Reath Warren (2020) lyfter fram hur språkideologier och språkhierarkier både i Sverige och i andra länder kan få betydelse för hur familjen väljer språk $\mathrm{i}$ modersmålsundervisning. Lagstiftningen i Sverige ger bara möjlighet att välja ett språk även om flera språk talas i hemmet och då väljer familjen ofta det språk som ges högst status (Reath Warren, 2021). Vad som ligger bakom valet av arabiska i Jamils familj framgår inte av berättelsen mer än att det är mammas val och att Jamil uttrycker att han också borde lära sig turkiska.

Viktigt i Jamils berättelser om resor till ursprungslandet är att han gillar pappas berättelser och att pappa kallar Jamil för kompis. I pappans berättelser finns också en förankring bakåt i tiden, genom att han berättar om minnen från sin barndom. I den här delen av berättelsen framträder emotioner som kärlek och en känsla av gemenskap när han berättar om hur han och pappa gör saker som är förankrade i pappans barndom och släktens historia. Jamil uttrycker tydligt att han saknar att kunna dela det turkiska språket med sin pappa. 
Avvaktande och ambivalent - Jamil positionerar sig genom bur berättelsen berättas Nästa nivå i analysen fokuserar hur Jamil positionerar sig i relation till mig $\mathrm{i}$ samtalet, det vill säga med fokus inte bara på vad som sägs utan också hur berättelsen berättas. Jamil uttrycker ofta explicit sina åsikter och vad han känner. Hur han positionerar sig varierar mellan samtalen. Han prövar olika positioner, särskilt i relation till att vara svensk, en annan sorts svensk eller turk. I mina memosanteckningar har jag ibland tolkat det som att han tror att det är det jag förväntar mig att våra samtal ska handla om, och ibland utifrån att det här är något han faktiskt funderar mycket på just nu $\mathrm{i}$ livet. Berättandet pendlar då mellan att ha en mer redogörande funktion, det vill säga att prestera "rätt" berättelse för en intervju, och en mer terapeutisk funktion. Den emotion som framträder tydligast har jag därför kallat för en form av avvaktande ambivalens. $\AA$ ena sidan säger han att han känner sig udda i ̊̊byn och som att han har en känsla av att han egentligen skulle bo någon annanstans. Han drömmer ibland om att gå $i$ en annan skola, i Turkiet, men där samlas barnen runt honom och tittar och frågar och han känner att det är på ett annat sätt än i Sverige. Barnen leker till exempel andra lekar. Jamil återkommer ofta till att han inte kan turkiska och att hans pappa har valt att prata svenska med honom istället och i det framträder en sorts sorg och saknad.

\section{Yasmines berättelse}

Yasmine går i årskurs fyra på Vikenskolan. Hennes föräldrar är från Irak. Själv är hon född i Sverige och har bott i Viken hela sitt liv, men har varit i Irak på besök en gång. Där bor också många av Yasmines släktingar. Hon har modersmålsundervisning i arabiska. Så här berättar Yasmine om skolan, sin familj och sina språk:

Jag kommer ihåg att det var konstigt när jag började skolan. Alltså jag kände ingen då. För jag fick inte med mig någon från mitt dagis. Jag var själv som gick där. Det var flera år som jag kände mig ensam. Nu har jag många kompisar på skolan, för i min klass är det flera som pratar arabiska. Jag är med dem.

Man kan gå till typ Kerstin [sva-läraren, min anm.]om man är ledsen eller så. Eller till Åsa och Bertil [klasslärarna/mentorerna, min anm.]. Mamma och pappa frågar Osman [modersmålslärare, min anm.] och Osman frågar Bertil och Åsa. Och så svarar de på utvecklingssamtalen eller så ringer de hem. På utvecklingssamtalen har de tolk. Det är lite olika folk. 
En timme i veckan går jag till Osman, på fredagar. Vi brukar skriva och läsa. Så att jag lära mig mycket mer arabiska. Jag kan inte lära mig arabiska om jag är själv. Jag gillar om det är som en klass. Det är mycket bättre för mig, att lära fortare. Så att om jag åker till arabiska länder, så kan jag skriva, prata, läsa och sånt. För jag är arab. Men i Irak känner jag mig svensk också.

När jag gick i förskolan hade jag en annan fröken i arabiska. Men Osman har jag också haft länge. Jag går hos Osman så att jag ska lära mig arabiska. Jag tycker om det jättemycket att vara hos honom. Jag kanske åker någon gång till Irak eller flyttar dit och börjar skolan. Då kanske jag behöver kunna arabiska, sitta vid datorn och det kanske står något på arabiska, då måste jag kunna det. Jag kan lite. Typ, vi har bokstäver som är ihop. Det är inte likt svenska. Osman pratar samma arabiska som jag. Det är inte samma arabiska i Kuwait. För arabiska är Koranens språk, det är också arabiska fast det är annorlunda. Och när man ber. Jag är inte så bra för det är svårt i Koranen. Men min kusin, han lär oss.

Vi brukar umgås mest med släkten här i Viken. Alla kvinnorna brukar samlas i en lokal och prata och sånt. Det är en jättestor, alla samlas där och vissa hämtar mat och vi äter och vi är olika grupper, då. Kvinnorna är själva och tjejerna och barnen själva också. Männen, de är inte med oss. Det är bara kvinnor. Vi har den varje lördag. Och männen har den varje dag, fast inte på lördagar för att då har vi den. Alla som vill får vara där, men alltså då menar jag bara muslimer. Alla pratar arabiska då. Det är faktiskt kul för då träffar man alla och jag känner alla. Fast ibland brukar det komma vissa från stan. I lördags var vi där och läste Koranen, som vi brukar göra och sen åt vi och sen så började alla sätta sig på olika platser och prata och sånt.

Den första nivån $\mathrm{i}$ analysen fokuserar vilka karaktärer som finns med i berättelsen och hur de positioneras i förhållande till varandra i berättelsen. Det finns flera karaktärer som framträder som viktiga för hennes relationer till språk i hennes berättelse. Viktiga karaktärer är kvinnorna och flickorna i den lokal på orten där de samlas på lördagar samt kusinen som undervisar 
dem i Koranen. De karaktärer i skolan som berättas fram är Osman (modersmålsläraren), Kerstin (sva-läraren) samt Åsa och Bertil (klasslärarna/ mentorerna). En person som Yasmine positionerar som mycket viktig för henne och hennes familj i skolan är just modersmålsläraren Osman. Han fungerar som en länk mellan skolan och hemmet. När hon berättar om honom, om modersmålsundervisningen och om klassrummet där undervisningen bedrivs blir hon känslomässigt berörd. I mina memosanteckningar har jag beskrivit hur hon ser glad ut, verkar stolt och berättar med allvar i rösten. Syftet med en analys med ett analytiskt fokus på emotionella positioneringar, som framträder både explicit och implicit i berättelsen, är att göra det möjligt att förstå den emotionella ambivalens som eleverna hanterar i sina berättelser. Emotionell ambivalens innebär att känslor är komplexa och ofta både positiva och negativa på samma gång (Svašek, 2010; Zembylas, 2012), i synnerhet i relation till så komplexa fenomen som migration, språk och tillhörighet. Det är därför värdefullt och viktigt att uppmärksamma det emotionella arbete som framträder i berättelser som Jamils och Yasmines, för att inte förenkla eller ta ett sådant arbete för givet. Vill man ta berättelsen fullt ut på allvar, kan man då inte bortse från det som framträder mellan raderna.

\section{Modersmålet som oundgänglig resurs - Yasmine positionerar sig själv och karaktärerna $i$ berättelsen}

Yasmine positionerar sig som en tjej som när hon har arabiska kompisar är trygg och glad i skolan. Hon positionerar sig även som en ambitiös elev i skolans modersmålsundervisning. Hon har ett mål med den arabiska hon vill lära sig, nämligen att kunna använda språket i tal och skrift och i ett framtida yrkesliv, kanske i Irak. Yasmine beskriver modersmålsundervisningen som något som ger henne handlingsmöjligheter. Hon positionerar sig som muslim och arabiskan beskrivs som nödvändig för att lära sig Koranen, men också som gemensamt språk i den kvinnliga gemenskapen i lokalen. Yasmines berättelse visar hur modersmålsundervisningen får betydelse på många av de olika sätt som Straszer och Wedin (2020) lyfter fram, det vill säga som resurs kunskapsmässigt och socialt (se artikelns inledning). Modersmålet, arabiskan, har stort värde för familjen, sociala nätverk och religionen för Yasmine. För henne är arabiskan en viktig kunskapsresurs och ett viktigt redskap för att utöva islam, det vill säga för att läsa Koranen och för bön. Arabiskan har också ett stort socialt värde för Yasmine, både i skolan och utanför skolan både i skolan och utanför skolan när det gäller familjen, släkten, kompisar och då de träffas i lokalen på lördagar. En emotion som framträder är en känsla av stolthet.

\section{Stolt! - Yasmine positionerar sig genom hur berättelsen berättas}

Nästa nivå $\mathrm{i}$ analysen fokuserar hur Yasmine positionerar sig $\mathrm{i}$ relation till mig i samtalet, det vill säga med fokus på hur berättelsen berättas. På ungefär 
samma sätt som Jamil prövar hon olika positioner som handlar om att vara svensk eller arab. I hennes berättelse framträder en tydlig arabisk identitet, som hon visar främst genom att på olika sätt försöka få mig att förstå hur hon menar och att jag inte ska tycka att något verkar konstigt. "För jag är arab. Men i Irak känner jag mig svensk också”. Hon prövar på samma sätt som Jamil sina identiteter och hon uttrycker det inte så explicit i ord som Jamil, men hon återkommer ständigt till temat $\mathrm{i}$ de tre intervjuerna och även $\mathrm{i}$ ett annat sammanhang som handlar om stolthet över att bära sjal (Ljung Egeland, 2015). På den mindre orten där Yasmine bor är det inte så vanligt. I mina memosanteckningar står att när Yasmine pratar om sig själv som arab, muslim och med sjal, iakttar hon mig och avvaktar hur jag ska reagera och vad jag ska säga, men hennes stolthet är den mest framträdande känslan. Yasmine använder också många arabiska ord när hon berättar för mig om sin resa till Irak, om islam eller annat $\mathrm{i}$ hennes vardag $\mathrm{i}$ hemmet. Hon har ibland svårt att berätta om Irak och arabiska traditioner på svenska, eftersom det är en domän där hon använder arabiska. Hon hittar strategier för att förklara för mig, men ser det som enklast under intervjun att lära mig vad det heter på arabiska.

\section{DISKUSSION}

Vad säger då de här berättelserna om ämnet modersmål i skolan? Handlar de inte om mycket annat? Jo, men den som har intervjuat elever om skolan och bett dem berätta om specifikt undervisning vet att det kan bli ganska fåordigt, tunt och framstå mer som en utvärdering av läraren. Är hen bra eller dålig? Vad är roligt och vad är tråkigt? Att be eleverna berätta om sina liv i och utanför skolan kan göra det möjligt att få kunskap om hur eleverna skapar mening kring sina erfarenheter av språk och modersmålsämnet. Vad betyder ämnet för dem? Genom att intervjua eleverna flera gånger och med en narrativ utgångspunkt blir det möjligt att ta ett bredare perspektiv på ämnet modersmål och modersmålsundervisning och diskutera i relation till känsla av tillhörighet och olika identitetsrelaterade frågor. Eleverna i den här studien inbjuds att berätta om språk och modersmålsundervisning, men också om mycket annat, som sociala nätverk, minnen, familj, kompisar och fritid. De konstruerade berättelserna visar hur de i samtalen på olika sätt försöker få mig att förstå vad modersmålsämnet och undervisningen betyder för dem. Samtalen tar olika riktningar, men det är inte en slump vad och hur de berättar. Erfarenheterna är tydligt situerade och det är något de vill kommunicera så att jag ska förstå och de använder olika narrativa resurser, som blickar, tonfall, kroppsspråk och bildspråk.

Vilka möjligheter knyts då till bestämda språk och språkliga resurser? När Jamil och Yasmine av olika anledningar investerar eller inte investerar i modersmål och modersmålsundervisning hänger det mycket samman med deras föreställda identiteter i framtiden och vilket symboliskt och materiellt 
kapital det kan ge tillgång till, som att bli inkluderad i en grupp eller gemenskap, få kärlek, ekonomisk trygghet eller andra möjligheter. Det handlar om vem de tror att de kan och vill bli (Darvin \& Norton, 2015). Jamils och Yasmines erfarenheter skapar känslor som bär på specifik kunskap och motiverar dem att handla i olika riktningar eller investera i språk (Madrid m.fl., 2013). De positioneringar de gör när de berättar handlar om förhandling och det gäller också emotionerna, som är en viktig del i den sociala interaktionen. På motsvarande sätt utgör också sociala omständigheter en del av den emotionella erfarenheten. Yasmines känsla av stolthet får betydelse för både hennes självkänsla och för den sociala interaktionen både $i$ och utanför skolan, men även för interaktionen med mig i intervjusamtalet. Hennes känsla är inte bara avhängig av den egna förståelsen, utan också min och andras. Bamberg $(1997 ; 2004)$ lyfter fram det han å ena sidan kallar för master narratives eller dominerande berättelser och den som berättar gestaltar eller förhåller sig till dessa på ett eller annat sätt. Får jag där jag befinner mig vara stolt över arabiskan och att jag kan läsa Koranen samtidigt som jag klarar skolan på svenska? Detta försöker Yasmine genom sitt berättande och sina berättelser själv förstå och få mig att förstå och hur det hänger ihop i en komplex helhet.

Att som Jamil känna sorg och saknad, men också ambivalens, kopplat till språk hänger i hans berättelse till stor del ihop med känslor av tillhörighet och känslor av utanförskap. Emotioner är på så vis relaterade till den egna självbilden, relationer till andra och kulturella föreställningar som får betydelse för vad som ses som annorlunda, viktigt, möjligt, orättvist och så vidare. I Jamils berättelse framträder tydligt den emotionella betydelse föräldrarnas modersmål har för honom och för familjen och hur han fråntas möjligheten att lära sig turkiska på ett sådant sätt han skulle vilja genom dels föräldrarnas beslut om vilka språk som talas $i$ hemmet, dels genom skolans regelverk som inte gör det möjligt att få modersmålsundervisning $\mathrm{i}$ mer än ett språk. Inte någon hänsyn har tagits till barnets/elevens perspektiv. I Jamils berättelse framträder också känslor av ambivalens inför både det han beskriver som det svenska och det han möter i Turkiet. En modersmålslärare skulle kunna betyda mer än att vara en språklärare för Jamil. En modersmålslärare kan knyta an till och synliggöra de erfarenheter Jamil har från utanför skolan och därmed fungera som stöd i Jamils identitetsarbete.

I min avhandling (Ljung Egeland, 2015), som handlar om tretton barns berättade erfarenheter av känsla av tillhörighet finns många berättelser om modersmålsämnet och modersmålsundervisningen. I berättelserna framträder mycket glädje och stolthet, men också mer ambivalenta känslor kopplade till ämnet. De flesta av eleverna beskriver hur modersmålsundervisningen i skolan är mycket viktig och betyder mycket på olika sätt. Dels handlar det om att få undervisning i modersmålet för att lära sig och utveckla språket, dels handlar det om att det också kan vara ett rum och "då finns jag och min familj där", som en elev uttrycker det. Han beskriver att det finns en lärare där som 
"vet", det vill säga kan erkänna och lyfta fram hans unika erfarenheter (s. 174). Det $\mathrm{i}$ andra sammanhang osynliggjorda blir synligt. En annan elev har erfarenhet av att även om skolan försökte, var det inte möjligt att hitta en modersmålslärare i karen och hon önskar ibland att hon kunde flytta till en annan stad där det finns modersmål i det språket. För några elever betyder dock undervisningen inte lika mycket och ett fåtal elever i studien positionerar sig som ganska ointresserade av modersmålsundervisningen i skolan eller att det räcker med en kort lektion i veckan. Andra beskriver att det är just den korta tiden som gör att det inte känns som någon idé att ha någon lektion. Det eleverna vill eller skulle vilja investera ser olika ut, men sammantaget framträder ämnet modersmål i elevernas berättelser som viktigt för den språkliga och kulturella identiteten.

Narrativt inriktad forskning med, om och för barn har som all annan forskning sina utmaningar och utvecklas ständigt teoretiskt och metodologiskt (se Moran m.fl., 2021). Med den här artikeln har jag velat illustrera hur berättelser är kontextuella, det vill säga hur sammanhanget både skapar och reflekterar hur barn och unga berättar (Mishler, 1986) och hur berättandet i sig blir en ny erfarenhet. Kraften, kreativiteten och rikedomen den narrativa ansatsen kan ge i utforskandet av sådana komplexa fenomen som lärande, identitet, tillhörighet och agens är ett viktigt kunskapsbidrag till pedagogisk forskning. Det finns stor potential i kunskap om elevers erfarenheter för att förstå samhällsinstitutioner som skolan och familjen utifrån elevers perspektiv. Att berätta kan vara ett första steg till att se möjligheter och hinder för förändringsprocesser och därifrån utveckla utbildning och undervisning.

\section{REFERENSER}

Ahmed, Sara (2004). The cultural politics of emotion. Edinburgh University Press.

Alanen, Leena (2001). Childhood as a generational condition: Children's daily lives in a central Finland town. I Leena Alanen, \& Berry Mayall (Red.), Conceptualizing child-adult relations (ss. 129-143). RoutledgeFalmer.

Ansell, Nicola (2005). Children, Youth, and Development. Routledge Perspectives on Development, Routledge.

Bamberg, Michael (1997). Positioning between structure and performance. Journal of Narrative and Life History, 7(1/4), 335-342. doi:10.1075/jnlh.7.42pos

Bamberg, Michael (2004). "I know it may sound mean to say this, but we couldn't really care less about her anyway": Form and functions of "slut bashing" in male identity constructions in 15-year-olds. Human Development, 47(6), 331-353. doi:10.1159/000081036 
Bjerén, Gunilla, \& Elgqvist-Saltzman, Inga (1994). The life-line approach in social science. I Gunilla Bjerén, \& Inga Elqqvist-Saltzman (Red.), Gender and education in a life perspective: Lessons from Scandinavia (ss. 8-17). Avebury.

Brady, Louca-Mai, \& Graham, Berni (2019). Social Research with Children and Young People: A Practical Guide. Policy Press.

Brinkmann Svend (2008). Identitet: Udfordringer i forbrugersamfundet. Klim.

Brinkmann, Svend (2010). Positionering. I Leksikon for det 21. Arhundrede. Hämtad 2021-03-10, från http://www.leksikon.org/art.php?n=5172

Bryman, Alan (2011). Sambällsvetenskapliga metoder. Liber.

Bucholtz, Mary (2009). Why be normal? Language and identity practices in a community of nerd girls. I Nikolas Coupland, \& Adam Jaworski (Red.), The new sociolinguistics reader (ss. 215-228). Palgrave Macmillan.

Burr, Vivien (2003). Social constructionism. Routledge.

Clandinin, D. Jean, Huber, Janice, Huber, Marilyn, Murphy, M. Sean, Murray Orr, Anne, Pearce, Marni, \& Steeves, Pam (2006). Composing diverse identities: Narrative inquiries into the interwoven lives of children and teachers. Routledge.

Clandinin, D. Jean, Pushor, Debbie, \& Orr, Anne Murray. (2007). Navigating sites for narrative inquiry. Journal of Teacher Education, 58(1), 21-35.

doi:10.1177/0022487106296218

Cummins, Jim (2017). Flerspråkiga elever: Effektiv undervisning i en utmanande tid. Natur och kultur.

Darvin, Ron, \& Norton, Bonnie (2015). Identity and a Model of Investment in Applied Linguistics. Annual Review of Applied Linguistics, 2015/35, 36-56. doi:10.1017/S0267190514000191

David, Miriam, Edwards, Rosalind, \& Alldred, Pam (2001). Children and schoolbased re-search: Informed consent or educated consent? British Educational Research Journal. 27(3), 347-365. https://doi.org/10.1080/01411920120048340

De Fina, Anna, \& Georgakopoulou, Alexandra (2012). Analyzing narrative: Discourse and sociolingustic perspectives. Cambridge University Press.

Dencik, Lars (1995). Välfärdens barn eller barns välfärd? Om tillsyn, hänsyn, och felsyn. I Lars Dahlgren \& Kenneth Hultqvist (Red.), Seendet och seendets villker: En bok om barns och ungas välfärd (ss. 63-105). HLS.

Dencik, Lars (1999). Fremtidens barn: Om postmoderniseringen og socialisering. I Lars Dencik, \& Per Schultz Jörgensen (Red.), Born og familie $i$ det postmoderne samfund (ss. 19-44). Hans Reitzels forlag.

Duek, Susanne (2017). Med andra ord: samspel och villkor för litteracitet bland nyanlända barn. [Doktorsavhandling. Karlstad University Studies 2017:4, Karlstad Universitet].

Eckert, Penelope (2008). Variation and the indexical field. Journal of Sociolinguistics, 12(4), 453-476. https://doi.org/10.1111/j.1467-9841.2008.00374.x 
Eilard, Angerd (2009). Barns perspektiv som kunskapskälla: Om barnintervjun i

Skolinspekt-ionens kvalitetsgranskningsarbete. Skolinspektionen, avdelningen i Lund.

Fontes, Lisa Aronson (2008). Interviewing clients across cultures: A practitioner's guide. Guilford Press.

Freeman, Mark (2010). Hindsight: The promise and peril of looking backward. Oxford University Press.

Garvis, Susanne, Ødegaard, Elin Eriksen, \& Lemon, Narelle (2015). Beyond Observations: Narratives and Young Children. Brill Sense

Harré, Rom, Moghaddam, Fathali M. Cairnie, Tracey Pilkerton, Rothbart, Daniel, \& Sabat, Steven R. (2009). Recent advances in positioning theory. Theory \& Psychology, 19(1), 5-31. https://doi.org/10.1177/0959354308101417

Karlsson, Marie (2006). Föräldraidentiteter i livsberättelser. [Doktorsavhandling, Acta Universitatis Upsaliensis, Uppsala universitet].

Keselman, Olga (2009). Restricting participation: Unaccompanied children in interpretermediated asylum hearings in Sweden. [Doktorsavhandling, Institutionen för beteendevetenskap och lärande, Linköpings universitet].

Ljung Egeland, Birgitta (2015). Berättelser om tillhörighet: om barn med migrationsbakgrund på en mindre ort. [Doktorsavhandling, Karlstad University Studies 2015:31, Karlstads universitet].

Ljung Egeland, Birgitta (2018). Berättande och berättelser om flerspråkighet. I BethAnne Paulsrud, Jenny Rosén, Boglárka Straszer, \& Åsa Wedin (Red.), Transspråkande $i$ svenska utbildningssammanhang (ss.131-148). Studentlitteratur.

Löfdahl, Annica (2012). Barn- och barndomsforskning + god forskningssed = sant? I A. Löfdahl, \& H. Pérez Prieto (Red.), Barn, barndomar, rättigheter och utbildningar: Vänbok till Solveig Hägglund (ss. 96-108). Karlstads universitet.

Madrid, Samara, Baldwin, Nikki, \& Frye, Eleanor (2013). Professional feeling: One early childhood educator's discomfort as a teacher and learner. Journal of Early Childhood Research, 11(3), 274-291. https://doi.org/10.1177/1476718X13484240

Mishler, Elliot G. (1986). Research interviewing: Context and narrative. Harvard University Press.

Mishler, Elliot G. (1999). Storylines: Craft artists' narratives of identity. Harvard University Press.

Montgomery, Polly \& Bailey, Patricia H. (2007). Field Notes and Theoretical Memos in Grounded Theory. Western Journal of Nursing Research, 29(1), 65-79. https://doi.org/10.1177/0193945906292557

Moran, Lisa, Reilly, Kathy, \& Brady, Bernadine (2021). Narrating Childhood with Children and Young People: Diverse Contexts, Methods and Stories of Everyday Life. Palgrave McMillan.

Morgan, Alice (2004). Vad är narrativ terapi? Mareld. 
Norton Peirce, Bonnie (1995). Social identity, investment, and language learning. TESOL Quarterly, 29(1), 9-31. https://doi.org/10.2307/3587803

Ochs, Elinor (1993). Constructing social identity: A language socialization perspective. Research on Language and Social Interaction, 26(3), 287-306. https://doi.org/10.1207/s15327973rlsi2603_3

Ochs, Elinor, \& Capps, Lisa (2001). Living narrative: Creating lives in everyday storytelling. Harvard University Press.

Ongstad, Sigmund (1999). Vad är positioneringsanalys? Självpositionering i en (post)modern skola som exempel. I Carl-Anders Säfström, \& Leif Östman (Red.), Textanalys (ss. 148-176). Studentlitteratur.

Pérez Prieto, Héctor (2006). Erfarenhet, berättelse och identitet: Livsberättelsestudier. Karlstads universitet.

Polkinghorne, Donald E. (1995). Narrative configuration in qualitative analysis. Qualitative Studies in Education, 8(1), 5-23. https://doi.org/10.1080/0951839950080103

Randall, William L. (2010). The narrative complexity of our past. Theory and Psychology, 20(2), 147-169. https://doi.org/10.1177/0959354309345635

Reath Warren, Anne (2020). Modersmålselevers syn på språk och modersmålsämnet. I Boglárka Straszer, \& Åsa Wedin (Red.), Modersmål, minoriteter och mångfald i förskola och skola. (ss. 273-332). Studentlitteratur.

Reath Warren, Anne (2021). Heteroglossia in mother tongue instruction in Sweden and the development of plurilingual literacies. Pragmatics and Society, 12(1), 106-131. https://doi.org/10.1075/ps.18016.rea

Scheff, Thomas J. \& Starrin, Bengt (2002). Skam och sociala band - om social underordning och utdragna konflikter. I Anna Meeuwisse, \& Hans Svärd (Red.), Perspektiv på sociala problem (ss. 167-184). Natur och kultur.

Sharif, Hassan (2016). Ungdomarnas beskrivningar i mötet med introduktionsutbildningen för nyanlända: "Inte på riktigt, men jätteviktigt för oss". I Pirjo Lahdenperä, \& Eva Sundgren (Red.), Skolans möte med nyanlända (ss. 92-110). Liber.

Skrbiš, Zlatko (2008). Transnational families: Theorising migration, emotions and belonging, Journal of Intercultural Studies, 29(3), 231-246.

https://doi.org/10.1080/07256860802169188

Straszer, Boglárka, \& Wedin, Åsa (2018). Rum för transspråkande i modersmålsundervisning. I BethAnne Paulsrud, Jenny Rosén, Boglárka Straszer, \& Åsa Wedin (Red.), Transspråkande i svenska utbildningssammanhang (ss. 217-241). Studentlitteratur.

Straszer, Boglárka, \& Wedin, Åsa (2020). Modersmål i svenska skolan introduktion. I Boglárka Straszer, \& Åsa Wedin (Red.), Modersmål, minoriteter och mångfald i förskola och skola. (ss. 24- 35). Studentlitteratur. 
Svašek, Maruška (2010). On the move: Emotions and human mobility. Journal of Ethnic and Migration Studies, 36(6), 865-880.

SOU 2019:18. Förflerspråkighet, kunskapsutveckling och inkludering: modersmålsundervisning och studiehandledning på modersmål. Betänkande av Utredningen om modersmål och studiehandledning på modersmål i grundskolan och motsvarande skolformer.

Utbildningsdepartementet.

van Langenhove, Luk, \& Harré, Rom (1999). Introducing positioning theory. I Rom Harré, \& Luk van Langenhove (Red.), Positioning theory: Moral contexts of intentional action (ss. 14-31). Blackwell Publishers.

Vuorenpää, Sari, \& Zetterholm, Elisabeth (2020). Modersmålslärare - så mycket mer än språklärare. I Boglárka Straszer, \& Åsa Wedin (Red.), Modersmål, minoriteter och maingfald i förskola och skola. (ss. 303-329). Studentlitteratur.

Zembylas, Michalinos (2012). The politics of fear and empathy: emotional ambivalence in 'host'children and youth discourses about migrants in Cyprus. Intercultural Education, 23(3), 195-208. 